\title{
Exploring Effects of Place Attachment on Home Return Travel: An spatial perspective
}

\author{
Tingting Elle Li* \\ Middlesex University London, Hendon Campus \\ E-mail: t.li@mdx.ac.uk
}

Bob McKercher

School of Hotel and Tourism Management, The Hong Kong Polytechnic University

Bob.Mckercher@polyu.edu.hk

For citation please use: Li, T. E., \& McKercher, B. (2016). Effects of place attachment on home return travel: a spatial perspective. Tourism Geographies, 18(4), 359-376.

*Corresponding author 


\begin{abstract}
Recent studies on place-mobility relationships suggest increasing possibility of people's multiple place attachment or place attachment in varied spatial scales. Yet our understanding of how place attachment in different spatial scales affects mobility remains limited. This study investigates home return visit by Chinese diaspora tourists from North America who have made multiple trips to China. 29 in-depth interviews with repetitive home return travellers were conducted in a highly explorative way. Four different types of return movement were identified: local; dispersed; local \& dispersed; and secondmigration locale focused. A relationship was found between the participants' sense of place, place identity and home return travel. The findings suggest that home return travel is more complex than previously thought. More focused sense of place and strong personal connection to ancestral home may lead to more local return, while more generic sense of place and collective personal identity would result in more dispersed travel. Family migration history and strong attachment to family's first migration destination would lead to focused return to the place. The study highlights the fact that place and place attachment are deeply personal and can evolve over time and space. Practical contributions were made by providing illuminating instructions to diaspora destinations.
\end{abstract}

Keywords: Home return travel; repeat visitation; place attachment; place identity; Chinese diaspora; North America

\title{
Introduction
}


Interest in travel by migrant and/or diasporic communities to their countries of origin is growing in recognition of both the social significance of this activity to the individual and its economic importance to both source markets and destinations (Dwyer, Forsyth, King \& Seetaram, 2010). Various terms are used to describe this type of travel, including diaspora tourism (Coles \& Timothy, 2004; Cohen, 2004; Hughes \& Allen, 2010), home return travel (Duval, 2004; Nguye \& King, 2002), ethnic tourism (Feng \& Page, 2000; Kang \& Page, 2000), roots tourism (Basu, 2005; Pinho, 2008) and visiting friends and relatives (Pearce, 2012). Regardless of the term, though, it is generally believed people return to their ancestral homelands in order to help construct their own identities or to resolve personal identity crises (Lew \& Wong, 2004; Duval, 2004; Dwyer et al., 2010; Iorio \& Corsale, 2013; Basu, 2007; Marcus \& Fischer, 1986), sustain, renew or create family and cultural ties (Hollinshead, 2004; Lew \& Wong, 2004; McCain \& Ray, 2003), as a journey of selfdiscovery (Franklin \& Crang, 2001), as a quest for 'the other' (Van den Berghe, 1994) or for many other reasons.

While much of this work is informative, the spatial context of what constitutes 'home" ${ }^{1}$ is rarely delineated, and as a result, little work has been conducted examining the behavioral patterns of home return tourists. Yet, reading the above works suggest recent migrants see 'home' in narrow spatial terms of their home community. Alternately, studies of individuals with longer migration histories tend to suggest they see 'home' more at a more generic nation level, which may or may not include a specific community of origin (Hughes \& Allen, 2010). In addition, individuals with disrupted migration patterns who cannot lay claim to a specific ancestral home community, such as former African migrants and much of the Jewish diaspora, view the idea of 'home' as an amorphous, symbolic and mythic space (Safran, 1991; Levitt \& Waters, 2002). Yet, all still claim some type of attachment to these places.

This observation suggests place attachment can have varying spatial contexts. If so, then one would also expect that home return travel patterns may be more complex than previously thought and may also be influenced by or reflect difference spatial senses of place and place attachment. This paper presumes that movement patterns will be more focused among these with a strong and 
localized sense of place, while those who exhibit less robust place attachment to their ancestral home community will engage in more dispersed travel. A qualitative method using a sample of Chinese diaspora tourists who are residents in North America is adopted.

\section{Research Context}

\section{Place and Place Attachment under Growing Mobilities}

Located in geographical space, maintaining a physical setting through activities conducted and meanings grasp (Relph, 1976), place is seen as not only maintained a nature of "physicality" but also sustained its connections and exchanges with the surroundings, which is considered as being vital (Tuan, 1977). Human geographers started to recognize the difference between space and meaningful place by believing that places are extracted by ordinary people from continuous and abstract space to a bounded, identified, meaningful, named, and significant place (Relph, 1976; Tuan, 1975). To Massey (1991), people's perceptions toward places are highly complicated, varied in different social groups and how people relate to it. Places are perceived as meaningful by both individuals and social groups (Gustafson, 2006), who have different perceptions toward a place based on their own understandings and needs.

Place attachment which has been portrayed as a multifaceted concept refers to as the bonds between people and place based on affection, cognition and practice (Low \& Altman, 1992; Scannell \& Gifford, 2010). Scannell and Gifford (2010) comprehend place attachment through a tripartite framework. They define the 'process' dimension by involving affective elements representing the emotional connection a person has with a place and can be expressed in a positive manner as a sense of happiness, pride, love and wellbeing (Hummon, 1992; Brown, Perkins \& Brown, 2003), or by an equal sense of grief, sadness and feeling of longing when displaced from a place (Fried, 1963); cognitive elements of memory, knowledge, beliefs and meaning, people construct place meaning and closeness and connect it to the self (Hay, 1998; Twigger-Ross \& Uzzell, 1996) and behavioural elements that expressed 
through actions, typified by the idea of 'proximity-maintaining behavior' and expressed through length of stay or efforts to return (Hay, 1998), or through the reconstruction of a place after disaster or relocation (Geipel, 1982; Michelson, 1976). The 'person' dimension implies place attachment occurs at both individual and group levels. At the individual level, it involves one's personal connections to a place. Sometimes this bonding can be stronger when the place evokes personal memories, experiences, and feelings (Manzo, 2005). This aspect of place attachment is thought to contribute to a stable sense of self (Twigger-Ross \& Uzzell, 1996), that individuals draw similarities between themselves and the place and incorporate cognitions about physical environment into their self-definitions. At the group level, place attachment involves symbolic meanings shared among group members (Low \& Altman, 1992), such as shared historical experiences, values and symbols which can be transmitted to subsequent generations. The 'place' dimension is indicated in two levels: social and physical (Riger \& Lavrakas, 1981). Social attachment consists of social ties, belongingness to the place, and familiarity with people residing in the place. Physical attachment or 'rootedness' can be predicted by length of residence, ownership, and plans to stay.

Another crucial concept to comprehend place attachment is place identity (Proshansky, 1978), which is considered as a fundamental component of personal identity (Hernández, Hidalgo, Salazar-Laplace \& Hess, 2007). Place identity describes people's interaction with places in terms of feeling belonging to a specific place (Stedman, 2002). This identity can be either from an individual level self-concept, defining self as being part of a village, country, or even region, or from a perceived membership in a social group (or groups) together with the value and emotional significance attached to that membership (Tajfel, 1981; Hay, 1998).

Importantly, place is absolutely not static (Massey, 1994; Gieryn, 2000; Gustafson, 2006). Likewise, place attachment is a fluid concept that people can have multiple strong attachments to different places and some of which may evolve along time (Gustafson, 2006). This notion contradicts the historical belief that place attachment and mobility were mutually exclusive. Strong place attachment was believed to be indicative of immobility and low place 
attachment reflected higher rates of mobility (Relph, 1976). Today, this assumption is recognized as no longer being valid as increased mobility, transnationalism and improved transport technology now make it possible for people to develop and maintain strong ties to multiple places simultaneously. Mobility and place attachment are not theoretically opposite to each other. Instead, the experiences of people in a place involve both place attachment and mobility, and a more subtle and complex association exists with differing and often multiple place attachments evolving over time (Gustafson, 2009). It is particular the case that some migrants remain rooted in their home place and do not change, others integrate fully with the new host society, some develop multiple place attachments, remain simultaneously mobile and rooted, and some become rootless (Gustafson, 2001; McHugh \& Mings, 1996; Williams \& McIntyre, 2012).

However, the existence of different spatial scales of place attachment and how they interact with mobility has remained uncertain. Forty years ago, Tuan (1975) suggested that as people become more educated and more mobile, the scale of their identification changes from purely local (neighborhood) and national (country) to regional and cosmopolitan. Neighbourhood is one of the favourite scales, yet scarce empirical data has included larger scales, such as region, country, and continent. It may be because the belief that direct phenomenological experience converts abstract space into personally meaningful places, and larger scales like a region, a country or a continent are 'far too big to be directly experienced by most of its people' (Tuan, 1975, p158). Thus, country is usually seen through its symbolic value and rooted deeply in a common history and particularly strong socially constructed symbols of group belonging and identity (Lewicka, 2011).

Few studies have examined attachment at different spatial scales. Laczko (2005) included country, continent and more local scales and found that participants reported the strongest attachment to their country and the least attachment to their continent. In Gustafson's (2009) study, three groups of Swedish citizens with differing mobility levels (frequent travellers, occasional travellers, and non-travellers) were investigated. Frequent travellers expressed stronger macro level bonds (such as to 'Europe') and were also more willing to 
live abroad. Lewicka (2010) examined the effects of place scale on place attachment by looking at five scales of places (apartment, house, neighbourhood, city districts, and city) and confirmed the curvilinear and Ushaped relationship between scale of place and strength of attachment to the place. In her later research, she noticed that absence can make the heart grow fonder, for some people who have been away from their homes developed even stronger ties as a way to maintain their local identity (Lewicka, 2011).

'Attachment to what or at what scale?' then emerges as a key question that needs to be asked when thinking of the relationship between place and diaspora travel. Individuals with a strong localized place identity and attachment with their ancestral home may restrict their home return travel narrowly to the immediate environs of their home. Those with multiple attachments to different geographic locales, more generic place identity with the home place or a stronger attachment to their current home country may display more dispersed travel patterns.

\section{Diaspora tourism and home return travel}

The widespread dispersal of diasporic communities has greatly stimulated the travel of this population between source and destination countries (Dwyer et al., 2010). The production and consumption of such kind of travel show the growing attention to how immigrants with dispersed families maintain their family life and friendships (Feng \& Page, 2000; Hall, 2005; Janta, Cohen \& Williams, 2015). Place attachment, as a crucially important sense experienced in diaspora tourism, has been researched in this literature under different expressions, including 'home connection', 'home ties', 'sense of home', 'belonging', 'home identity' and etc. Visits home are associated with the functions of maintaining kinship and social relations (Koppenfels, Mulholland \& Ryan, 2015), committing care duties and family obligations (Janta et al., 2015), affirmation of homeland identity (Janta et al., 2015), searching for ancestral roots (Pinho, 2008), and repeated negotiation a sense of belonging or continuously struggling with 'the others' (Wagner, 2015). Nonetheless, multigenerations of diaspora members would have much complex sense of place. 
Those with extensive familial and social ties and a self-ascribed diasporic membership travel back with past non-tourist experiences to maintain or extend such ties (Duval, 2004). Individuals with limited connection to their roots travel with a strong desire to search for their roots or to discover an ancestral perspective of self (Pinho, 2008).

Thus, diaspora travel is thought to have involved diverse practices with blurred and sometimes overlapping boundaries, displaying complex and different timespace patterns (Mueller, 2015). Diaspora tourists display varied degrees of home attachment, sometimes as 'nolstalgia' (Hui, 2011), that motivates them to return to seek for 'sameness' and similar cultural footholds (Hollinshead, 2004), or for a quest for 'the other' and experiencing the 'difference' and 'change' in ancestral homeland during their absence (Van den Berghe, 1994). Therefore, it is the purpose of this study to explore how different scales of place attachment affects the return travel by multiple generations of diasporic individuals.

\section{Migration Waves and Return Tourism in China}

The Chinese have a long migration history to North America (Light, 1984; Pan, 1998), with three key migration waves noted: the Gold Rush (1840-1900), Post World War II/Post China Civil War (1945-1978) and Post Open-Door Policy (1979-present) (Wang \& Lo, 2005; Kemp \& Chang, 2004; Li, 1998; Skeldon, 1996). Until recently, most migrants originated from southern China, with an estimated 3.75 million overseas Chinese tracing their roots to the Jiangmen Wuyi Region of Guangdong Province (Jiangmen Government, 2010). Almost all of the first wave of migrants were men, who came to North America during the California Gold Rush or to work on railway construction (Government of Canada, 2012). This wave continued until the late 1800s when the United States implemented the Chinese Exclusion Act in 1882, followed by similar legislation introduced in Canada. These overtly racist Acts achieved their desired goals of effectively excluding Chinese migration for a period of almost 60 years (Kemp \& Chang, 2004). The result was the creation of a remnant 
Chinese population that settled in or was forced to settle in ethnic Chinatown ghettos.

The second wave occurred in the aftermath of the Chinese Civil War in the early 1950s. Most were political and economic migrants who left China with the hope of returning once the political situation stabilized (Li, 1998). As a result many moved initially to nearby Asian locations such as Hong Kong, Taiwan and Vietnam for extended periods of time, before on-migrating to their final destination in North America when it became clear they could not return home (Con \& Wickberg, 1982; Kemp \& Chang, 2004). Many raised families in these intermediate locales set down some roots.

The third wave began with the introduction of China's Open Door Policy in 1978, when the Central Government permitted its citizens to move voluntarily to developed countries for better life quality, employment opportunities and education for children. These migrants originated throughout China and moved mostly for life-style reasons. They tended to be well educated professionals (King \& Locke, 1980; Skeldon, 1996). Unlike others, they grew up in mainland China with a solid sense of place and strong Chinese identity, cared about the development of their motherland and strove to maintain their Chineseness after migration (Mei et al., 2001).

The implementation of the Open Door Policy in 1978 greatly stimulated the arrival of foreign tourists and overseas Chinese through gradually loosening the travel and political policies. This booming of international arrivals was significant until the occurrence of the Tiananmen Square incident in 1989 which caused a sharp decrease in the number of visitors and might have influenced the visit of overseas Chinese and compatriots (Cheng \& Ngok, 2013). Although the official agency did not have the information on how many diaspora tourists coming back to China each year, their trip purposes, travel destinations or patterns, it is believed that the remarkable growth of international arrivals in China was attributed to the increase in the return travel of Chinese diaspora, compatriots from Hong Kong, Macau and Taiwan (Tisdell \& Wen, 1991). Chinese official organizations, private sectors and 
overseas Chinese associations all increased their involvement in promoting the return of the Chinese diaspora.

Importantly, return travel by the Chinese diaspora displayed differing features in terms of return form, time, destination and activities during visit. The 'old overseas Chinese' (Laohuaqiao) who migrated during or before the 1950s valued filial piety and social capital much especially during their first time of travelling home (Lew \& Wong, 2004). They involved actively in the communities of 'old overseas Chinese' and preferred more to travel back on specific ceremonial days or festivals. Whist the new Chinese migrants who migrated in more recent period were considered to be different in terms of their education level, career development and assimilation level in the host society. They travel with multiple purposes of visiting friends and relatives, business and leisure and their return may be closely related to new technologies, products and foreign investments (Zhao, 2001). Moreover, successive descendants of early Chinese immigrants are also an important part of the Chinese diaspora tourists. They engage more often in group tours arranged by family members or organized by travel agencies and Chinese communities in host countries. Their return travel is considered more as 'roots tourism' through which they visit their ancestral village, seek family roots, and learn Chinese traditions and culture (Guangdong OCAO, 2008). Despite the immense market potential of Chinese diaspora tourism, there is still limited attempts to study their travel patterns and underlying reasons.

\section{Research Design and Method}

A qualitative research approach, using a snowball sampling technique was used to recruit respondents for this study. Initial contact with potential respondents was conducted through such organisations as the Overseas Chinese Affairs Office in Jiangmen, China and Chinese Consolidated Benevolent Associations (CCBA) in San Francisco, Los Angeles and Vancouver. To qualify for inclusion, respondents had to be ethnically Chinese and must have made multiple return trips to China in the past 10 years. A total of 27 individuals (as shown in Table 1) participated in the study which is 
deemed suitable for qualitative research (Bertaux, 1981; Morse, 1994). The saturation was considered to occur by evaluating the adequacy and the comprehensiveness of the results until no new information was obtained (Morse, 1994; Bowen, 2008). The sample includes 19 first-generation migrants, whose family migrated to North America from the late 1940s onward. The other 8 were born in North America to ethnic Chinese whose families migrated between anywhere from the 1860 s to the late 1900 s. The sample consisted of 18 men and 9 women, aged from 20 to 79 . Seven had multiple migration histories, moving first from their original homes to Hong Kong or Taiwan and then onto their final destinations in North America. All respondents had made between two and more than 10 return visits to China in the past ten years. In order to preserve confidentiality, respondents' names have been omitted and instead they have been identified by a code based on the location where the interview was conducted and the interview number.

Insert Table 1 about here

In-depth, semi-structured interviews were conducted with questions focusing on four major themes: migration history, personal identity, place attachment (general perspective and ancestral home attachment), and home return travel. Each interview lasted about one hour and was conducted in the language that the interviewee felt most comfortable with (Cantonese/Mandarin/English). Interviews were translated into English and coded. Content analysis, which enables meanings underlying the physical messages to be explored and also helps identify thematic clusters to draw inferences from the data (Miles \& Huberman, 1994), was used to interpret the results.

Trustworthiness is considered to be vital in both qualitative and quantitative studies, methods and paradigms. Based on Lincoln and Guba's (1985) criteria and Shenton's (2004) steps, the researchers attempted to achieve a trustworthy research by addressing credibility through demonstrating a true representation of the phenomenon supported by multiple data sources collected in different population from four locations, transferability through providing adequate details of the research context, method, and instruments for readers to 
understand whether the findings can be applied to similar contexts, dependability by illustrating research design and implementation, operational details and a reflective evaluation on researchers' own positionality (e.g. authors' migration experience and whether their personal experience influences the data collected or information coded), and confirmability by demonstrating all of the findings emerge from the data rather than from own assumptions.

Several limitations of the research should be acknowledged. First, most of our respondents are middle-aged who have sufficient life experiences and income level to be capable of conducting multiple return visits. Most of them have joined overseas Chinese associations and have maintained a kind of attachment to ancestral home. Second, the authors recruited the respondents through an official agency based in Jiangmen. Thus, more respondents were Chinese immigrants or descendants with Jiangmen descent. This might cause geographical limitation for this research. Chinese diaspora members from other parts of China can be included in future research for further understanding of their return characteristics.

\section{Findings - Four Travel Patterns}

Four different home return patterns emerged which were influenced by the individual's migration history, specificity of personal and national identity and strength of affective, cognitive and behavioral connections to ancestral hometowns. Each is discussed below.

\section{Type 1: 'Local' - Ancestral Home Focused}

Seven individuals displayed a 'local' return travel pattern that they confined their journeys to the immediate environs of their ancestral homes. All are firstgeneration migrants with relatively recent migration histories, who demonstrated strong and enduring affective and cognitive attachments to their hometowns. In all cases, the interviewees maintained strong social and familial ties in their hometowns and four of them still owned houses there. They 
defined themselves as being from these communities, more so than simply being 'Chinese', and saw themselves as insiders because of their enduring individual and group ties. To a large extent, their strongly local place identity engendered place dependence that superseded their attachments to their migration destinations. Their travel frequency is very high (ranging from once to several times per year). To them, a return trip made them feel like they were going home. Respondents used such terms as 'emotional' 'happy' or 'proud' to state their feeling.

For example, 30-year-old respondent LA5 migrated from Jiangmen to San Francisco with his parents in 1990 and has since settled in Los Angeles. His strong affection and cognition towards Jiangmen derived from enduring family ties there. He considers his personal identity as being from Jiangmen, and he ensures that he travels back at least once a year. He commented:

I guess it is my family education, the media associated with me, and my friends around me make me feel Jiangmen is my home...I travel back almost once a year for visiting my grandmother. She is getting older and I want to accompany her as much as I can.

Another participant who was originally from Taishan (SF3) has retained deep connection to his home region Siyi. In his knowledge, he is always a Siyiren (people from Siyi region). His strong social bonds to ancestral home region make him very active in different Chinese communities in San Francisco. Most of his return trips were tied to tours organized by four migrant associations he belonged to, but all returned to his home community. These trips represented a significant part of his life, as he noted:

Our Siyi region associations have our own activities and invite local officials to attend. We normally attend an association conference, hold a memorial ceremony for our ancestors, then we go back to Jiangmen to attend other Chinese overseas activities. Each year is like this. 
The case of JM3 is very interesting, for her place attachment from ancestral hometown to 'a second hometown' through marriage and social ties. She was born in Shantou, migrated to Los Angeles in 1990 and got married there to another overseas Chinese with Jiangmen roots. She defines herself as Chinese, but interestingly has developed strong ties to her husband's hometown as well as to her ancestral home. Most of her home return travel, though, is to his ancestral home and, in fact, she has led multiple tours to Jiangmen to witness and participate in the homeland's development. She explained her travel as follows:

I developed strong attachment to Jiangmen Region because of my husband and my godfather's strong influence. I have done a lot more to Jiangmen than to my own ancestral hometown, for I had this special feeling to Jiangmen. First, it is the influence of my god father, he dedicated his lifetime to bringing more Chinese overseas back home. Now I continue to do what he did...Second, I feel that the high rank government officials in Jiangmen are more friendly. Communications between various parties are common and pleasant.

\section{Type 2: 'Dispersed' Type}

In contrast to members of the local group, five respondents represented the 'dispersed' group of home return tourists. Their trips were typified by travel to China's major cities and/or tourist nodes, with little travel to not travel to their ancestral homes. Likewise, their motives were associated more with typical business travel or pleasure travel motives of sightseeing and exploration than with visiting friends and relatives or maintaining strong community ties. This group of individuals had either multi-generational longer migration histories, or if recent migrants felt they had assimilated almost totally to the west. As a result they described themselves as being both Western and Chinese, with their Chinese identity being a function of their ethnic background, rather than being place based. They present a cognitive level of attachment to generic China by stating that 'China is their ancestral home' and they are 'familiar with most Chinese traditions, values, and culture'. 
Respondent JM4 is typical. He was born and raised in Guangzhou and migrated to Toronto 30 years ago. He expressed equal attachment to China and Canada, seeing himself as 'culturally more Chinese, but behaviorally more Canadian'. He visited China three to five times primarily to conduct business and if time permits to attend local events, and contribute to the environmental protection of his homeland. Each visit includes multiple stops, but only occasionally does he visit his ancestral home. He explained the reasons:

Perhaps because I don't make geographical distinction of the place... I grew up in Guangzhou, but each time I would visit multiple cities and did not spend much time there. I don't have much feeling about the place and only return where the things have to be done... Many concepts like emotions, habits, self-identity and etc., they are not contradicting to each other. When I am in Canada, I act and think like a Canadian. I will do the same when I am in China: try to think and act like a Chinese. I have some core values that will not change easily, but my identity is mixed.

The experiences of VA4, a 50-year-old Chinese Canadian from Vancouver, is typical of individuals whose families migrated many generations ago. Her maternal family migrated to Canada in late 1800 s, while her father did not come to Canada until 1948. She considers herself as a third-generation Chinese Canadian who grew up in a white-dominant environment. Although she was not sure whether there was an attachment between her and China, her connection to China became apparent from her father's side. She said that:

It was quite clear that I am Chinese in Canada... my father was very interested in China and he opened a Chinese communist bookstore. He imported all the magazines from 1970 s to 80 s. I can sing the communist songs in Mandarin. I can sing 'Beijing Tiananmen', but I did not know what Beijing was or what Tiananmen was [at that time]... I did not quite understand what 'Chinese in Canada' meant until I went to China. Then I realized that there was a whole huge population of Chinese people that lived in somewhere. 
She made her first visit in 1974, when she joined a youth group and returned to her ancestral village Taishan for a week. She came back a couple of times afterwards with her parents or independently to multiple destinations, including Taishan, Beijing, Shanghai and Suzhou. She thought her identity 'shifted depending on what age she was'. After all these years, her Chinese attachment has shifted as well to a more expansive sense as being a 'Chinese in Canada with strong Chinese roots'. She feels closer to Beijing than to her hometown because she lived in Beijing for a couple of years and spent most of her time in China in the North. Thus, there was 'more impression to Beijing'.

\section{Type 3: 'Hybrid Local or Dispersed' Depending on Purpose}

A group of 12 respondents showed more varied travel patterns, engaging in localized journeys on some trips and travel to other places in China on other trips. These people tend to engage in travel to their hometowns to visit friends and relatives, but unlike members of the 'local' group, they also engage in leisure or business travel to other localities in China. Their migration histories are also somewhat different. Eight were first-generation migrants migrated to North America during 1970s to 2000s. The other four individuals had their ancestors migrated during 1880 s to 1900 s. Despite of the varied migration histories, when asked about their identities and attachments, they represent hybrid feelings that displayed both strong ties to their ancestral homes and a more broadly based collective identity as Chinese. Their sense of place at local level reflect both emotional and cognitive attachment to the place. They maintained strong connection with the local communities much like the 'local' group. While their attachment to China was reflected from a self-identification as being both, or equally associated with their ancestral home specifically and China more generally. Thus, they also engaged in travel to other parts of China and demonstrated strong collective identities as Chinese. They too have a very high return frequency and their length of stay varies from a couple of days to several months depending on their return purpose.

Respondent JM2 left China in 1976 due to family poverty and migrated illegally to Hong Kong first and then four years later moved to America where 
he spent many years as a waiter in a local Chinese restaurant. He maintained a personal identity as being a Xinhui overseas Chinese. But, his experiences in the United States have also helped foster an identity as being Chinese which transcends his local roots, enabling him to contribute to broader diasporic Chinese community. He stated that:

Maybe because I had very tough moment in the beginning [of living in the US], I still have very strong emotional feelings toward Jiangmen Xinhui. I would never forget the truth that I was forced to leave my hometown and the hard times in US. So I consider Jiangmen Xinhui as my first and only hometown. I return almost every year and spend several months... While, as a Chinese, I have been a member of a Chinese overseas association since 2000 and have travelled to Beijing, Shanghai, and Hong Kong occasionally for Chinese overseas events.

Another example is LA6, a 63-year-old Chinese American whose grandfather first left China to California during 1900s to work in a farm. She was born and raised in China until she was three years old. When the Immigration of the United States allowed her mother to come to America, her mother left in 1951. It was 1953 when she left China to Hong Kong and lived there for three years until she finally settled down in the US. On one hand, she maintained a strong personal attachment to her ancestral home Zhongshan from a cognitive way expressing that 'Zhongshan is where my roots are'. On the other hand, she developed a strong personal identity as being Chinese and valued her social and familial ties to China overseas Chinese community. She expressed her feelings as:

I still have a cousin living in Zhongshan. He is like my brother. I feel very proud of being one of the first to see China before the Cultural Revolution and being able to witness all the changes. I almost travel back every year, engaged in both localized trips to Zhongshan and dispersed trips to Hong Kong, Guangzhou, Nanjing, Shanghai, Suzhou, Hangzhou for my consultant work.

SF5 migrated from her hometown Panyu of Guangzhou city to San Francisco in 1980s when she was 20. She still had personal ties to Guangzhou, with 
several aunts and uncles living there. However, she saw herself as being both Chinese and from her home community, by noting 'when I talk about motherland, I will think of China'... [but] 'if we talk about hometown, I will definitely think of Guangzhou'. She described having nostalgia and enjoyed frequent trips to Panyu to visit friends and relatives, as well as took leisure trips to big cities like Beijing and Shanghai.

Type 4: The 'Second-migration' Type Centered in Family's First Migration Destination

A fourth group emerged that consists of three people who moved initially from China to an intermediary destination in Taiwan or Hong Kong during their formative years and then ultimately migrated to North America. Members of this group feel stronger ties to their first, temporary migration destination than to their ancestral homes. They present group ties to ancestral home culture, but see their ancestral home as a meaningful place to their parents. In a sense then, their place attachment is to the liminal space they occupied between China and their current home, much from a cognitive perspective to generic China, recognizing that 'it is important to value my Chinese background'.

Respondent SF1 was born in Hong Kong. He moved to San Francisco with his parents when he was six. Despite his early memories in Hong Kong, he maintained strong affective attachment to family's first migration destination, saying that he "still have memories about Hong Kong and love for Hong Kong Cuisine'. He fit into the American society very well and had lots of American friends. He saw himself as a Chinese American with strong Western characteristics. His attachment to Hong Kong was obvious:

Hong Kong is a very developed and convenient place to live. I even think about returning to Hong Kong after my retirement. By contrast, when we visited my ancestral hometown Xinhui, I felt like we were visiting some third-world country. My return now is mostly to Hong Kong, and sometimes conduct temporary trips to other cities in China. For example, my recent trip in 2009, I brought my daughters back to China and visited several cities including Xinhui. 
The parents of respondent LA7 moved to Taiwan from Fujian during the Chinese Civil War. She was born in Taiwan and stayed there for 26 years before coming to the United States in 1974 as a college student. She felt attached both to Taiwan and her current home in Los Angeles, but had no affinity to her ancestral home. She identified herself as 'in-between' two cultures as 'a mix of Chinese, Taiwanese, and Chinese American'. She saw herself as ethnic Chinese rather than belonging to local community in ancestral hometown. She described her return travel:

My travel is all about family reunion to Taiwan where we still have a lot of family members. I did conduct one trip back to my ancestral hometown in 1988 , but it was undertaken because I wanted to accompany my father and my husband... Some parts of the trip were emotional. However, some unpleasant things happened during our tour which really affected my feelings. Local people in the village thought we are rich and can take advantage of that. So I don't feel like going back again.

\section{Discussion and Conclusions}

The purpose of this study was to explore the effects that place and place attachment have on return travel by members of the Chinese diaspora resident in North America. The study assumes that movement patterns will be more focused among these with a strong localized sense of place, while those who exhibit less robust place attachment to their ancestral home community will engage in more dispersed travel. In doing so, it also sought to determine whether 'place' in varying spatial dimensions affect diasporas' home return travel patterns. Four discrete types of return travel were identified as summarized in Table 2.

Insert Table 2 about here 
Respondents belonging to both the 'local' and 'second migration' groups tended to restrict their return travel largely to the immediate environs of a single community where they still had strong affective and cognitive attachments. Return travel was motivated primarily by the desire to go 'home' and to maintain existing links as an insider. The key difference was that members of the 'local' group were attached to their ancestral homes, while the 'second-migration' group were attached to intermediate places where their families migrated temporarily before ultimately settling in North America. In each case though, respondents spent their formative years in these places. Members of these groups demonstrate strong examples of place dependence and place identity (Stokols \& Shumaker, 1981; Proshansky, 1978) based on deep personal and immediate experiences. Their home attachment is also expressed stronger in an individual dimension (Scannel \& Gifford, 2010) that their home place evokes personal memories, experiences and emotions associated with a localized self-identification (Twigger-Ross \& Uzzell, 1996).

Members of the 'dispersed' tourist tended to identify themselves as being ethnically Chinese, but their sense of place was more strongly rooted in North America. They had weak ties to their ancestral homes, and instead, ties to China were at a more amorphous or generic level representing cognitive and group/cultural dimension of place attachment. They visited many places when they travelled to China which may or may not include a side trip to their ancestral home. Moreover, their trip motives were quite varied from rootsseeking to business/leisure.

Members of the 'local \& dispersed' group represented some elements of the aforementioned groups. They engage in both local trips and dispersed travel and perceive their hometown as a major destination during their trips. They maintain strong personal connections with the home community in terms of affection and cognition level. They clearly have stronger individual place attachment and identify themselves as being part of the hometown community as well as Chinese overseas community.

This study builds on the work of Gustafson (2001) and Lewicka (2011) by suggesting the effects of spatial dimension of place attachment on home return 
travel are far more complex than often imagined. Particularly in the context of diaspora, sense of place may be focused narrowly on the immigrant's ancestral home or on intermediate places where they spent significant amounts of time as youth. It may also be perceived in national scope that may not necessarily be specifically place based. The study further suggests a link exists between the spatial dimension of place, the nature of place attachment expressed by individuals and their home return movements. Localized movements are associated with individuals who have a strong private, individual affective and cognitive attachment to one place. More dispersed movements are likely to be seen among people who tend to have more of a group tie and identity as being Chinese, but whose specific attachments are to their current places of residence. As Lewicka (2011) argues, the relationship between place attachment and mobility are far from settled, with past studies examining how different forms of mobility result in different levels of attachment to permanent places (Gustafson, 2009; Van der Klis \& Karsten, 2009). This study suggests place attachment may also affect mobility, in terms of not only movement frequency, but also travel purpose and destination.

The study also highlights the fact that place and place attachment are deeply personal. Studies cannot make generalizations about any ethnic groups and their desire to go home. Instead of making generalizations, this study develops a deeper understanding of how the immigrants and their descendants consider home. By doing so, it suggests that the depth of attachment to ancestral home evolves over time and space as individuals become more attached elsewhere. Sometimes, their sense of home becomes expansive in scale due to formative years of living outside of it. In some cases, this sense can transfer to a second hometown through personal ties and experiences. Individuals' personal identity can be closely associated with their place attachment and it is also fluid and can change over time. As a result, travel patterns taken by diaspora tourists change too. Ali and Holden's (2006) work shows that as attachment to place changes, people are less willing to make return visits to 'home'. The findings of this study further imply that with changes of their attachment and personal identity, diasporas may not want to visit their ancestral homes, but 
still have a desire to visit the country of ethnic origin due to a more generic sense to the country.

This research can also make practical contributions to diaspora destinations by providing evidence for tourism officials and agencies on individuals' travel patterns, characteristics, and motives. It is suggested that over time migrants and those with multiple attachments will more likely take generic sightseeing trips to the country of origin, while recent migrants and those with strong personal ties will respond to home visit trips, but are unlikely to travel more widely. Thus, illuminating instructions can be provided to different geographical scales of places at home in terms of branding themselves into a favourable and nurture place for immigrants and their descendants to visit.

This research provides several avenues for future research. Despite the limitations discussed in methodology section, future research could include the Chinese descendants with ties to other regions in China with a larger sample. Researchers could also conduct further investigation from the supply side of diaspora tourism by researching on the development of effective marketing strategies. The implications of diaspora tourism, including how diasporic members' repeat visitation influences the local community and how diaspora tourism influences immigrants' sense of well-being are two other directions for future research.

Notes:

1. The term 'home' adapted the meaning from the phenomenon 'home return travel' in migration and diaspora tourism context, symbolically indicating the place of origin and ancestral home of diaspora. 
References:

Ali, N., \& Holden, A. (2006). Post-colonial Pakistani mobilities: the embodiment of the 'myth of return' in tourism. Mobilities, 1(2), 217-242.

Basu, P. (2005). Roots tourism as return movement: semantics and the Scottish diaspora. In M. Harper (Ed.), Emigrant homecomings: The return movement of emigrants, 1600-2000 (pp. 131-150). Manchester: Manchester University Press. Basu, P. (2007). Highland homecomings: Genealogy and heritage tourism in the Scottish diaspora. New York: Routledge.

Bertaux, D. (1981). From the life-history approach to the transformation of sociological practice. In D. Bertaux (Ed.), Biography and society: The life history approach in the social sciences (pp. 29-45). London: Sage.

Bowen, G. A. (2008). Naturalistic inquiry and the saturation concept: a research note. Qualitative Research, 8(1), 137-152.

Brown, B., Perkins, D. D., \& Brown, G. (2003). Place attachment in a revitalizing neighborhood: Individual and block levels of analysis. Journal of Environmental Psychology, 23(3), 259-271.

Cheng, J. Y., \& Ngok, K. L. (2013). Government policy in the reform era: interactions between organs responsible for overseas Chinese and Qiaoxiang communities. Qiaoxiang Ties: Interdisciplinary Approaches to" Cultural Capitalism" in South China (London: Kegan Paul International, 1999), 113142.

Cohen, R. (2004). Global social movements. New York: The Athlone Press.

Coles, T., \& Timothy, D. J. (2004). Tourism, diasporas and space. London: Routledge.

Con, H., \& Wickberg, E. (1982). From China to Canada: A history of the Chinese communities in Canada. Toronto, ON: McClelland and Stewart.

Duval, D. T. (2004). Linking return visits and return migration among Commonwealth Eastern Caribbean migrants in Toronto. Global Networks, 4(1), 51-67. 
Dwyer, L., Forsyth, P., King, B., \& Seetaram, N. (2010). Migration-related determinants of Australian inbound and outbound tourism flows: STCRC.

Feng, K., \& Page, S. J. (2000). An exploratory study of the tourism, migration-immigration nexus: Travel experiences of Chinese residents in New Zealand. Current Issues in Tourism, 3(3), 246-281.

Franklin, A., \& Crang, M. (2001). The trouble with tourism and travel theory. Tourist Studies, 1(1), 5-22.

Fried, M. (1963). Grieving for a lost home. In L. J. Duhl (Ed.), The urban condition: People and policy in the metropolis (pp. 124-152). New York: Simon \& Schuster.

Guangdong OCAO. (2008). Overseas Chinese Youth Visited Jiangmen for Root-seeking. Retrieved on 2 Jun, 2009 from http://gocn.southen.com/qw2index/2006xgzl/2006xgbd/200905190005.htm.

Geipel, R. (1982). Disasters and reconstruction: The Friuli earthquakes of 1976. London: George Allen \& Unwin.

Gieryn, T. F. (2000). A space for place in sociology. Annual Review of Sociology, 26, 463-496.

Government of Canada. (2012). Facts and Figures 2011. Citizenship and Immigration Canada. Retrieved 7 May, 2013.

Griffin, T. (2013). Research note: A content analysis of articles on visiting friends and relatives tourism, 1990-2010. Journal of Hospitality Marketing \& Management, 22(7), 781-802.

Gustafson, P. (2001). Roots and Routes: Exploring the Relationship between Place Attachment and Mobility. Environment and Behavior, 33(5), 667-686.

Gustafson, P. (2006). Place attachment and mobility. In N. McIntyre \& K. E. McHugh (Eds.), Multiple dwelling and tourism: Negotiating place, home and identity (pp. 17-31): CAB International.

Gustafson, P. (2009). More cosmopolitan, no less local: The orientations of international travellers. European Societies, 11(1), 25-47. 
Hall, C. M. (2005). Tourism: Rethinking the social science of mobility. Harlow: Prentice Hall.

Hay, R. (1998). Sense of place in developmental context. Journal of Environmental Psychology, 18(1), 5-29.

Hernández, B., Hidalgo, M. C., Salazar-Laplace, M. E., \& Hess, S. (2007). Place attachment and place identity in natives and non-natives. Journal of Environmental Psychology, 27(4), 310-319.

Hollinshead, K. (2004). Tourism and third space populations. The restless motion of diaspora peoples. In T. Coles \& D. J. Timothy (Eds.), Tourism, diasporas and space. London: Routledge.

Hughes, H., \& Allen, D. (2010). Holidays of the Irish diaspora: the pull of the 'homeland'?. Current Issues in Tourism, 13(1), 1-19.

Hui, A. (2011). Placing nostalgia: The process of returning and remaking home. In T. K. Davidson, O. Park \& R. Shields (Eds.), Ecologies of affect: Place nostalgia, desire, and hope (pp. 65-84). Waterloo: Wilfred Laurier University Press.

Hummon, D. M. (1992). Community attachment: local sentiment and sense of place. In I. Altman, \& S. M. Low (Eds.), Place attachment (pp. 253-278). New York: Plenum Press.

Iorio, M., \& Corsale, A. (2013). Diaspora and tourism: Transylvanian Saxons visiting the homeland. Tourism Geographies, 15(2), 198-232.

Janta, H., Cohen, S. A., \& Williams, A. M. (2015). Rethinking visiting friends and relatives mobilities. Population, Space and Place, 21(7), 585-598.

Jiangmen Government. (2010). Jiangmen Government Report. Jiangmen Government.

Kang, S. K.-M., \& Page, S. J. (2000). Tourism, migration and emigration: travel patterns of Korean-New Zealanders in the 1990s. Tourism Geographies, 2(1), 50-65. 
Keith, M., \& Pile, S. (2004). Place and the politics of identity. New York: Routledge.

Kemp, C., \& Chang, B. J. (2004). China. In C. Kemp \& L. A. Rasbridge (Eds.), Refugee and immigrant health: A handbook for health professionals (pp. 132141). Cambridge: Cambridge University Press.

King, H., \& Locke, F. B. (1980). Chinese in the United States: A century of occupational transition. International Migration Review, 15-42.

Koppenfels, A. K., Mulholland, J., \& Ryan, L. (2015). 'Gotta Go Visit Family': Reconsidering the relationship between tourism and transnationalism. Population, Space and Place, 21(7), 612-624.

Laczko, L. S. (2005). National and local attachments in a changing world system: Evidence from an international survey. International Review of Sociology, 15, 517-528.

Levitt, P., \& Waters, M. C. (2002). The changing face of home: The transnational lives of the second generation. New York: Russell Sage Foundation.

Lew, A., \& A., W. (2004). Sojourners, guanxi and clan associations: social capital and overseas Chinese tourism in China. In T. Coles \& D. J. Timothy (Eds.), Tourism, diasporas and space. New York: Routledge.

Lewicka, M. (2010). What makes neighborhood different from home and city? Effects of place scale on place attachment. Journal of Environmental Psychology, 30(1), 35-51.

Lewicka, M. (2011). Place attachment: How far have we come in the last 40 years? Journal of Environmental Psychology, 31(3), 207-230.

Li, P. S. (1998). Chinese in Canada. Toronto: Oxford University Press.

Light, I. (1984). Immigrant and ethnic enterprise in North America. Ethnic and Racial Studies, 7(2), 195-216.

Lincoln, Y. S., \& Guba, E. G. (1985). Naturalistic inquiry. Beverly Hills, CA: Sage Publications. 
Low, S. \& Altman, I. (1992). Place attachment: A conceptual inquiry. In I. Althman \& S. Low (Eds.), Place Attachment, New York: Plenum.

Manzo, L. C. (2005). For better or worse: Exploring multiple dimensions of place meaning. Journal of Environmental Psychology, 25(1), 67-86.

Marcus, G. E., \& Fischer, M. M. J. (1986). Anthropology as cultural critique: An experimental moment in the human sciences. Chicago: University of Chicago Press.

Massey, D. (1991). A global sense of place. Marxism Today, June: 24-29.

Massey, D. (1994). Space, place and gender. Minneapolis: University of Minnesota.

McCain, G., \& Ray, N. M. (2003). Legacy tourism: The search for personal meaning in heritage travel. Tourism Management, 24(6), 713-717.

McHugh, K. E., \& Mings, R. C. (1996). The circle of migration: Attachment to place and aging. Annuals of the Association of American Geographers, 86, $530-550$.

Mei, W., Zhang, G., Zhang, Y., Guo, J., Guan, F., Gang, H., \& Dai, Y. (2001). The History of Wuyi Overseas Chinese (Vol. 1). Guangzhou: Guangdong Gaodeng Jiaoyu Chubanshe.

Michelson, W. (1976). Man and his urban environment: A sociological approach, with revisions. Reading, MA: Addison-Wesley.

Miles, M. B., \& Huberman, A. M. (1994). Qualitative data analysis: An expanded sourcebook (2nd ed.). Thousand Oaks, CA: Sage.

Morse, J. (1994). Designing funded qualitative research. In N. Denzin \& Y. Lincoln (Eds.), Handbook for qualitative research (pp. 220-235). Thousand Oaks, CA: Sage.

Mueller, D. (2015). Young Germans in England visiting Germany: Translocal subjectivities and ambivalent views of 'Home'. Population, Space and Place, 21(7), 625-639. 
Nguye, T.H., \& B. King (2002). Migrant communities and tourism consumption: The case of Vietnamese in Australia. In Hall, C. M. \& A. Williams (Eds.), Tourism and migration: New relationships between production and consumption (pp. 221-240). Morwell: Kluwer Academic.

Pan, L. (1998). The Encyclopedia of the Chinese Overseas Chinese. Singapore: Chinese Heritage Centre.

Pearce, P. L. (2012). The experience of visiting home and familiar places. Annals of Tourism Research, 39(2), 1024-1047.

Pinho, P. (2008). African-American roots tourism in Brazil. Latin American Perspectives, 35, 70-86.

Proshansky, H. M. (1978). The city and self-identity. Environment and Behavior, 10(2), 147-169.

Relph, E. (1976). Place and placelessness. London: Pion Limited.

Riger, S., \& Lavrakas, P. J. (1981). Community ties: Patterns of attachment and social interaction in urban neighborhoods. American Journal of Community Psychology, 9(1), 55-66.

Safran, W. (1991). Diasporas in modern societies: Myths of homeland and return. Diaspora, 1(1), 83-99.

Scannell, L., \& Gifford, R. (2010). Defining place attachment: A tripartite organizing framework. Journal of Environmental Psychology, 30(1), 1-10.

Shenton, A. K. (2004). Strategies for ensuring trustworthiness in qualitative research projects. Education for Information, 22(2), 63-75.

Skeldon, R. (1996). Migration from China. Journal of International AffairsColumbia University, 49, 434-455.

Stedman, R. C. (2002). Toward a social psychology of place predicting behavior from place-based cognitions, attitude, and identity. Environment and Behavior, 34(5), 561-581.

Stokols, D., \& Shumaker, S. A. (1981). People in places: A transactional view of settings. Cognition, Social Behavior, and the Environment, 441-488. 
Tajfel, H. (1981). Human groups and social categories. Cambridge: Cambridge University Press.

Tisdell, C., \& Wen, J. (1991). Foreign tourism as an element in PR China's economic development strategy. Tourism Management, 12(1), 55-67.

Tuan, Y. F. (1975). Place: An experiential perspective. Geographical Review, $65,151-165$.

Twigger-Ross, C. L., \& Uzzell, D. L. (1996). Place and identity processes. Journal of Environmental Psychology, 16(3), 205-220.

Van der Klis, M., \& Karsten, L. (2009). Commuting partners, dual residences and the meaning of home. Journal of Environmental Psychology, 29(2), 235245 .

Van den Berghe, P. L. (1994). The quest for the other: ethnic tourism in San Cristóbal, Mexico. University of Washington Press.

Wagner, L. (2015). Shopping for Diasporic Belonging: Being 'Local' or Being 'Mobile' as a VFR Visitor in the Ancestral Homeland. Population, Space and Place, 21(7), 654-668.

Wang, S., \& Lo, L. (2005). Chinese Immigrants in Canada: Their Changing Composition and Economic Performance1. International Migration, 43(3), 3571.

Williams, D. R., \& McIntyre, N. (2012). Place affinities, lifestyle mobilities, and quality-of-life. In M. Uysal, R. Perdue \& J. Sirgy (Eds.), Handbook of tourism and quality-of-life research (pp. 209-231): Springer.

Zhao, H. (2001). Characteristics of Chinese new migrants. Overseas Chinese Journal of Bagui, 2001(3), 4. (in Chinese). 